\title{
Occurrence of a Polychlorinated Biphenyl (PCB) Congener in Surface Water, Sediments and Blackchin Tilapia (Sarotherodon melanotheron) from Ologe Lagoon, Nigeria
}

\author{
${ }^{* 1}$ OBANYA, HE; ${ }^{2}$ NTOR, C; ${ }^{3}$ OKOROAFOR, CU; ${ }^{3}$ NWANZE, R \\ ${ }^{I}$ Environmental Assessment Department, Giolee Global Resources, Port Harcourt, Rivers State, Nigeria \\ ${ }^{2}$ Institute of Geoscience and Space Technology (IGST), Rivers State University, Rivers State, Nigeria \\ ${ }^{3}$ Ecotoxicology Unit, Department of Zoology, University of Lagos, Akoka, Yaba, Lagos, Nigeria. \\ *Corresponding Author Email: obanyahenry@gmail.com
}

\begin{abstract}
Polychlorinated biphenyls (PCBs) are persistent organochlorine chemicals that are toxic to aquatic organisms and humans. PCBs levels were assessed in surface water, sediments and fish from Ologe Lagoon, a major water body receiving treated effluents from Agbara Industrial Estate, using Gas Chromatograph-Electron Capture Detector (GCECD). 2,4,4'-Trichlorobiphenyl (2,4,4'-TCB) was the only PCB congener detected in the assessed matrices. Sediment $2,4,4$ '-TCB levels ranged from $0.0033 \pm 0.00333$ to $0.0430 \pm 0.00351 \mathrm{ng} / \mathrm{g}$. There was a significant $(\mathrm{p}<0.05)$ seasonal variation in the levels in sediments and surface water. The level in surface water from Zone 3 was above USEPA's safe limit $(0.0005 \mathrm{mg} / \mathrm{L})$ in the rainy season. There was no significant $(\mathrm{p}>0.05)$ seasonal difference in the mean concentrations of $2,4,4^{\prime}-\mathrm{TCB}$ in fish, and the levels were lower than WHO's safe limit $(0.2 \mathrm{mg} / \mathrm{kg})$. Based on the negligible to low levels of 2,4,4'-TCB in S. melanotheron inhabiting the lagoon, the fish was considered safe for consumption. Levels of 2,4,4'TCB found in the sediments and surface water in this study indicate that levels may change with season, therefore, we recommend that the concentrations of the compound are regularly monitored in order to timely avert toxic levels of bioavailable $2,4,4^{\prime}-\mathrm{TCB}$ in the water body.
\end{abstract}

DOI: https://dx.doi.org/10.4314/jasem.v23i10.6

Copyright: Copyright $(C 2019$ Obanya et al. This is an open access article distributed under the Creative Commons Attribution License (CCL), which permits unrestricted use, distribution, and reproduction in any medium, provided the original work is properly cited.

Dates: Received: 26 August 2019; Revised: 19 September 2019; 14 October 2019

Keywords: Polychlorinated biphenyls, Sarotherodon melanotheron, Sediments, Surface water.

Polychlorinated biphenyls (PCBs) are synthetic organochlorine chemicals that were used as coolants and lubricants in transformers, generators, and electrical capacitors because of their electrical insulating properties, low burning capacity and chemical inertness (Necibi and Mzoughi, 2017). They were also used in the production of plasticizers in rubber and polyvinyl chloride plastics (Erickson and Kaley, 2011). They were historically produced in the US and Europe (Gioia et al., 2013). Efforts have been made in those regions to significantly reduce the emissions of PCBs from their sources, however, high concentrations of these chemicals have been found in non-producing regions such as Africa (Gioia et al., 2013). Gioia et al., (2011) attributed these high levels to the atmospheric deposition of PCBs. Importation of fairly used and old electrical equipment from developed countries has also contributed to the increasing levels of the chemicals in the regions (Gioia et al., 2013). The high demand for electronic equipment and disposal of these products as e-wastes are regarded as important sources of PCBs in aquatic environments in Nigeria (Obaje, 2013). Aquatic ecosystems are usually the final destination of most wastes (Amiard-Triquet, 2015). Due to the persistent nature of $\mathrm{PCBs}$, those that end up in water and sediments can be taken up or bioaccumulated by aquatic organisms (Okoh, 2015). Biomagnification of PCBs along the food chain ultimately increases the levels of PCBs in aquatic organisms such as fish at higher levels of the food chain (Mackay and Fraser, 2000). Dietary exposure of PCBs to humans has been noted as an important route of exposure (Moon and Ok, 2006). Therefore, the monitoring of PCBs in aquatic foods such as fish is of importance because of the several effects of PCBs that have been observed over the years. The biological effects include carcinogenicity, immune suppression, neurobehavioural effects, hypothyroidism, infertility and reproductive system disorders, cardiovascular disease and elevated serum lipids, hypertension, diabetes, liver disease, asthma, arthritis, and low birth weight (Breivik et al., 2007). The Ogun - Lagos industrial axis has many sprawling industrial estates among which is the Agbara Industrial Estate. This estate hosts several large production plants which discharge their effluents, a possible source of PCBs, into the central sewage treatment plant which finally empties into Ologe Lagoon. The purpose of this study was to determine the levels of PCBs in environmental 
media (water and sediments) and fish of Ologe Lagoon.

\section{MATERIALS AND METHODS}

Study Area: Ologe Lagoon is a brackish coastal water body that covers about $6354.71 \mathrm{~km}^{2}$ and $285 \mathrm{~km}$ in area and perimeter respectively, and it lies in close proximity to Agbara Industrial Estate (Oluwatosin et al., 2008). Ologe Lagoon receives wastewater from the estate. The industrial estate has an integrated waste treatment plant that treats wastewater before discharging them into Ologe Lagoon via River Owo (Okogwu, 2006).

Sample Collection: Triplicate samples were collected from three zones of the lagoon (Fig. 1). Sampling was done in the rainy (May, 2017) and dry seasons (November, 2017). Water samples were collected using a $2.5 \mathrm{~L}$ amber glass bottle. Before analysis, samples were filtered through $0.45 \mu \mathrm{m}$ fibreglass filters to remove sand and debris. Sediments were also collected in situ using a fabricated $30 \mathrm{~kg}$ Van Veen Grab sampler. The sediments were subsequently retrieved, scooped into aluminium foil, wrapped and appropriately labelled. Fishes were collected using set nets. They were wrapped in aluminium foil, labelled and placed in coolers with ice packs until reaching the laboratory. Analyses began within 24 hours after collection. S. melanotheron was selected for this study based on its ecological and economic importance.

Analytical Procedure for Polychlorinated Biphenyls (PCBs) extraction and quantification: The extraction of the water samples was done according to the method of USEPA (2006a.) Briefly, $40 \mathrm{ml}$ of dichloromethane (DCM) was used to extract $200 \mathrm{ml}$ of the water sample twice. The extract was filtered through a funnel containing glass wool and $1 \mathrm{~g}$ of anhydrous $\mathrm{Na}_{2} \mathrm{SO}_{4}$ into an Erlenmeyer flask and then washed with $10 \mathrm{ml}$ of DCM. The combined sample extracts were concentrated to about $5 \mathrm{ml}$ using a rotary evaporator. The concentrated extract was dissolved in $40 \mathrm{ml}$ of n-hexane and further concentrated to $1 \mathrm{ml}$. The extract was solvent exchanged to $n$-hexane. The extract was transferred into a Florisil column twice pre-washed with $20 \mathrm{ml}$ of $\mathrm{n}$-hexane. Elution was done with $50 \mathrm{ml}$ of DCM/hexane (vol/vol ratio). The eluate was concentrated on a rotary evaporator until the volume reached $3 \mathrm{ml}$ and then further reduced to $1 \mathrm{ml}$ under a stream of nitrogen and solvent exchanged to $\mathrm{n}$-hexane. Extraction of sediment and fish samples was done in accordance with the methods described by Adeogun et al., (2016). Analyses were performed using a gas chromatograph (Agilent 7890A, Agilent Technologies, Palo Alto, CA, USA) with electron capture detection (ECD), and the results were confirmed by GC/MS (mass spectrometry) analysis. The GC-ECD column was an HP-5 fused silica column of $30 \mathrm{~m}$ length, $0.32 \mathrm{~mm}$ inner diameter and $0.25 \mu \mathrm{m}$ film thickness.

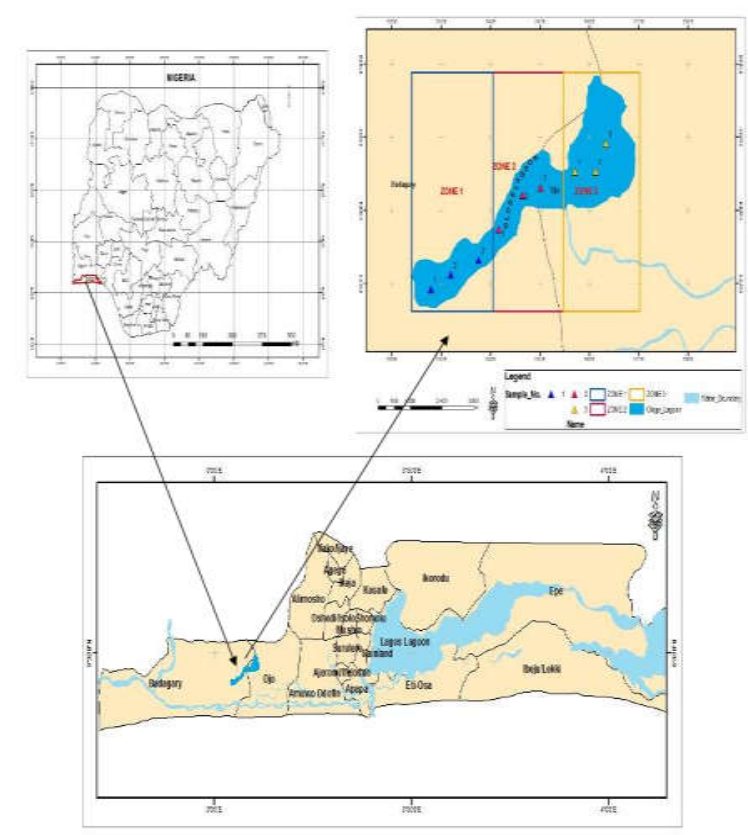

Fig 1: Map of Ologe Lagoon, Lagos, Nigeria (Adapted from Umulor et al., 2018)

Nitrogen was used as the carrier gas. The injector temperature was set at 280 and $320^{\circ} \mathrm{C}$ for the detector, the oven temperature was set at $70^{\circ} \mathrm{C}$ for a minute and increased to $170{ }^{\circ} \mathrm{C}$ at $40{ }^{\circ} \mathrm{C} / \mathrm{min}$, increasing at 3 ${ }^{\circ} \mathrm{C} / \mathrm{min}$ to $195^{\circ} \mathrm{C}$ (holding this temperature for $3 \mathrm{~min}$ ), increasing $0.5{ }^{\circ} \mathrm{C} / \mathrm{min}$ to $210{ }^{\circ} \mathrm{C}$ (holding for $5 \mathrm{~min}$ ) and increasing $20{ }^{\circ} \mathrm{C} / \mathrm{min}$ to $300^{\circ} \mathrm{C}$ with a final hold time of $10 \mathrm{~min}$ (Combi et al., 2013). A procedural blank was included with each set of samples. The recoveries for the compounds ranged from 80 to $110 \%$.

Biota-Sediment Accumulation Factor (BSAF): The biota-sediment accumulation factor (BSAF) was calculated as a ratio of the relative levels of PCBs in the fish and sediment samples. The BSAF is commonly used to support remedial decisions, and BSAF methodologies are clearly defined by USEPA (2006b).

$$
\text { BSAF }=\frac{\text { mean concentration of PCBs in fish }}{\text { mean concentration of PCBs in sediment }}
$$

\section{Bioaccumulation Factor (BAF)}

The bioaccumulation Factor (BAF) was calculated as a ratio of PCBs in the fish and surface water (USEPA, 2003). 


$$
\mathrm{BAF}=\frac{\text { mean concentration of } \mathrm{PCBs} \text { in fish }}{\text { mean concentration of PCBs in water }}
$$

Data Analysis: Data analyses were performed using SPSS version 20. Data were subjected to Two-way analysis of variance (ANOVA), and significant means $(\mathrm{p}<0.05)$ were separated using Duncan Multiple Range test. Results were expressed as Mean \pm Standard Error.

\section{RESULTS AND DISCUSSION}

Polychlorinated Biphenyls in the Environmental Media and Fish: Ologe Lagoon, a major 'receptacle' for industrial effluents from over 20 factories in Agbara Industrial Estate, was assessed to determine the levels of PCBs in sediments, water and fish from the water body. The results revealed that 2,4,4'Trichlorobiphenyl $\left(2,4,4^{\prime}-\mathrm{TCB}\right)$ also known as PCB 28 was the only detected PCB congener in the lagoon.

Sediments: The results from the sediment sample analysis indicated that the mean concentrations of $2,4,4$ '-TCB in sediments from the three zones ranged from $0.0290 \pm 0.00586$ to $0.0430 \pm 0.00351 \mathrm{ng} / \mathrm{g}$ during the rainy season and $0.0033 \pm 0.00333$ to $0.0100 \pm 0.00577 \mathrm{ng} / \mathrm{g}$ during the dry season (Figure 2). There was no significant $(\mathrm{p}>0.05)$ difference in the mean concentrations of $2,4,4^{\prime}-\mathrm{TCB}$ in sediments across the three zones. The mean concentration of $2,4,4^{\prime}$-TCB recorded in the rainy season was significantly $(\mathrm{p}<0.05)$ higher than the concentrations recorded in the dry season. Fu and $\mathrm{Wu}(2006)$ assessed the seasonal variation of the distribution of PCBs in sediments and biota in a PCB-contaminated estuary and observed that the concentration of PCBs in the sediments increased in the rainy season. They attributed the elevation in the concentration to the surface runoff of PCBs previously buried in the surface soil into the sediments. In other parts of Nigeria, PCBs levels in sediments from Choba River (0.1701 $\mathrm{\mu gg}^{-1}$ ) (Archibong et al., 2017), Ona River $(589-1353.6 \mu \mathrm{g} / \mathrm{kg}$ ) and Ogun River (322.9-2002.6 $\mu \mathrm{g} / \mathrm{kg}$ ) (Adeogun et al., 2016) were much higher than those in the present study. In comparison to studies conducted in other African countries and countries outside Africa, levels of the PCB compound in sediments in the present study were lower than most of the levels reported by Kampire et al., (2017) (1.60 to $3.06 \mathrm{ng}$ g-1; South Africa), Verhaert et al., (2013) (<50-1400 pg g-1 dw; Congo), Barakat et al., (2013) (1480-137,200 pg g ${ }^{-1}$; Egypt), de Souza et al., (2008) (18-184 pg g-1 dw; Brazil), Tombesi et al., (2017) (0.61 to $17.6 \mathrm{ng} \mathrm{g}^{-1}$; Argentina) Odabasi et al., (2017) (2.7-2450 $\mu \mathrm{g} \mathrm{kg}^{-1} \mathrm{dw}$; Turkey), Li et al., (2007) (0.03 - $13.99 \mathrm{ng} / \mathrm{g}$; China), and Kim et al., (2018) (18.1$136.8 \mu \mathrm{g} / \mathrm{kg}$; USA). These differences could lie on the specific industrial activities and sources of PCBs that release the chemicals into the various water bodies. Although the concentrations in sediments in the present study were relatively low, Obanya et al., (2018) asserted that chronic exposure to low concentrations of toxicants plays a greater role in toxicology than acute exposure.

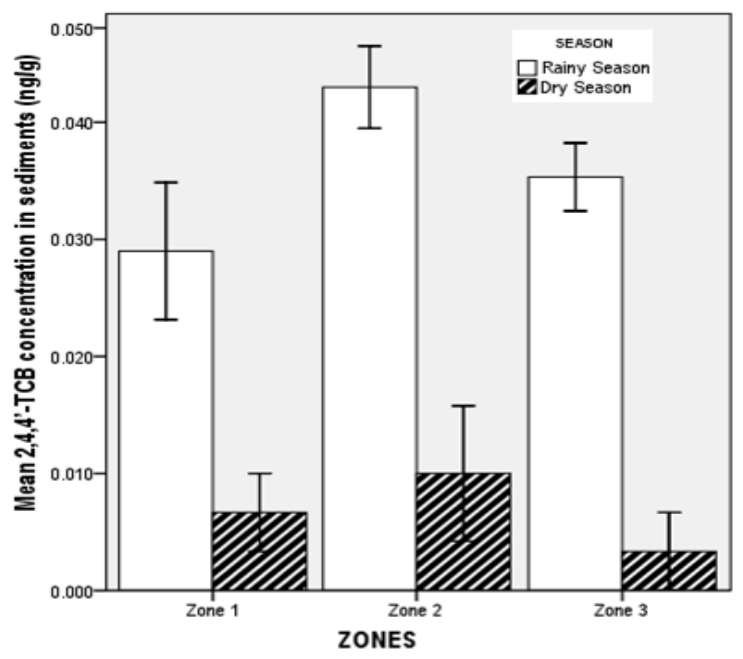

Fig 2: Concentrations of 2,4,4'-TCB in Sediments

Surface Water: The results obtained from the lagoon surface water analysis indicated that $0.00133 \pm$ $0.000667 \mathrm{mg} / \mathrm{L}$ of $2,4,4^{\prime}-\mathrm{TCB}$ was detected in surface water from Zone 3 during the rainy season (Figure 3). The PCB compound was not detected in surface water in the dry season (Figure 3). The variation between seasons was significant $(\mathrm{p}<0.05)$. The $2,4,4^{\prime}-\mathrm{TCB}$ value in water from Zone 3 during the rainy season was higher than the USEPA PCBs maximum limit for water $(0.0005 \mathrm{mg} / \mathrm{L})$ (USEPA, 2009). Organic contaminants are spread in the environment through water and air, however, they are expected to move to the sediments because organic contaminants are hydrophobic (Beyer and Biziuk, 2009). Similar studies in Nigeria (Ethiope, Benin and Warri Rivers (Ezemonye, 2005a; 2005b); Choba River (Archibong et al., 2017) had concentrations higher than the USEPA PCBs limit for water. Zone 3 is the closest zone to the point source of industrial effluents; this could explain the higher level of the detected PCB congener in relation to USEPA's safe limit. In the rainy season, the heavy rains tend to flush in more effluents from different sources into water bodies thus, the increase in the levels of various contaminants in water (Gao et al., 2013). Several studies have shown that PCBs in aquatic environments are toxic to inhabiting organisms at significant levels. The swimming velocity of Japanese medaka (Oryzias Latipes) exposed to $1-25 \mu \mathrm{g} / \mathrm{g}$ of PCBs decreased in a dose-dependent manner (Nakayama et al.., 2005). 
Lerner et al., (2007) reported that juvenile Atlantic salmon (Salmo salar) exposed to 1 and $10 \mu \mathrm{g} / \mathrm{L}$ of PCBs during smolting exhibited a dose-dependent reduction in preference for seawater. They also found that $10 \mu \mathrm{g} / \mathrm{L}$ of PCBs exposed juvenile $S$. salar exhibited a $50 \%$ decrease in gill $\mathrm{Na}+, \mathrm{K}+$-ATPase activity and a $10 \%$ decrease in plasma chloride levels in freshwater. Plasma triiodothyronine was significantly reduced in $S$. salar exposed to PCBs at 1 and $10 \mu \mathrm{g} / \mathrm{L}$ (Lerner et al., 2007). Gonzalez et al., (2016) observed that larval zebrafish (Danio rerio) treated with 2-10 ppm exhibited enhanced thigmotaxis (edge preference).

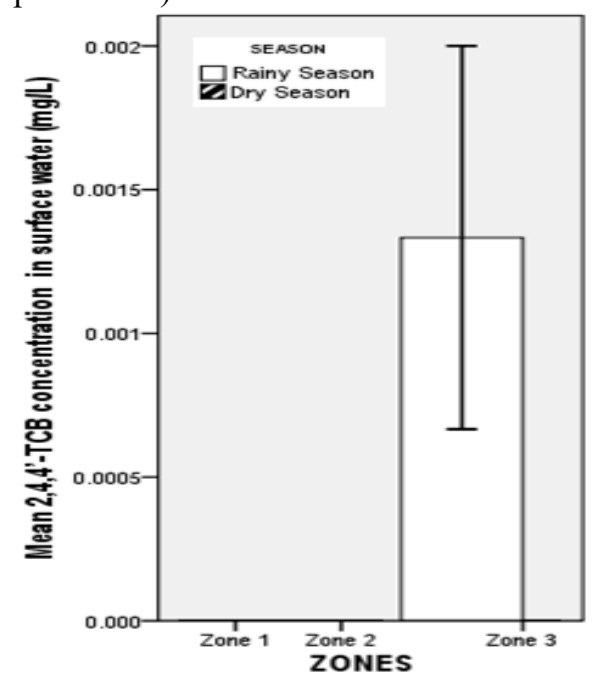

Fig 3: Concentrations of 2,4,4'-TCB in Surface Water

Bioaccumulation of $2,4,4^{\prime}$-TCB in the tissues of Blackchin Tilapia (S. melanotheron) inhabiting Ologe Lagoon: The mean concentrations of $2,4,4^{\prime}-\mathrm{TCB}$ in fish ranged from $0.0370 \pm 0.01739$ to $0.0533 \pm 0.00667$ $\mathrm{ng} / \mathrm{g}$ during the rainy season and $0.0367 \pm 0.00882$ to
$0.0467 \pm 0.01764 \mathrm{ng} / \mathrm{g}$ during the dry season (Figure 4). There was no significant $(\mathrm{p}>0.05)$ difference in the mean concentrations of $2,4,4^{\prime}$-TCB in fish across the three zones. Seasonal variation did not significantly $(p$ $>0.05$ ) affect the concentrations of $2,4,4^{\prime}-\mathrm{TCB}$ in fish. The mean concentrations of 2,4,4'-TCB in fish were lower than the WHO's safe limit $(0.2 \mathrm{mg} / \mathrm{kg}$ ) (WHO and FAO, 2011). The levels of 2,4,4'-TCB in the fish were low when compared to the levels reported in other parts of Nigeria and other countries (Table 1). The biota to sediment accumulation factor (BSAF) values of $2,4,4^{\prime}$-TCB in fish from the three zones ranged from 1.09 to 1.51 during the rainy season whereas during the dry season the values ranged from 0.48 to 14.15 (Table 2). The bioaccumulation factor (BAF) value of fish samples from zone 3 during the rainy season was $4.0075 \times 10^{-5}$ (Table 2 ).

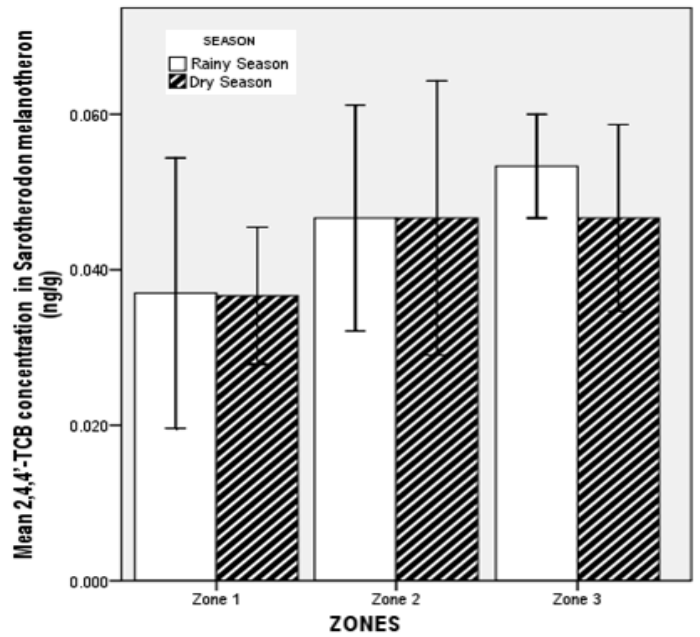

Fig 4: Concentrations of 2,4,4'-TCB in S. melanotheron

Table 1: PCBs levels in fish from other water bodies

\begin{tabular}{lll}
\hline Country & Levels & References \\
\hline Ologe Lagoon, Nigeria & $0.0367-0.0533 \mathrm{ng} / \mathrm{g}$ & Present study \\
Lagos Lagoon, Nigeria & 0.4228 to $2.94 \mathrm{ppm}$ & (Adeyemi et al., 2009; Igbo, 2012) \\
Choba River, Nigeria & $0.2683 \mu \mathrm{g} / \mathrm{g}$ & (Archibong et al., 2017) \\
Ogun River, Nigeria & $248.1-2433.6 \mu \mathrm{g} / \mathrm{kg}$ & (Adeogun et al., 2016) \\
Ona River, Nigeria & $421.7-2191.7 \mu \mathrm{g} / \mathrm{kg}$ & (Adeogun et al., 2016) \\
Lake Tanganyika in Burundi & $24,300-77,700 \mathrm{pg} \mathrm{g}^{-1} \mathrm{lw}$ & (Manirakiza et al., 2002) \\
Lake Burullus in Egypt & $3320-72,060 \mathrm{pg} \mathrm{g}^{-1}$ & (Said et al., 2008) \\
Lake Victoria, Uganda & 41 to $670 \mathrm{pg} \mathrm{g-1} \mathrm{lw}$ & (Ssebugere et al., 2014) \\
Pearl River Delta in China & 5150 to $226,000 \mathrm{pg} \mathrm{g}^{-1} \mathrm{lw}$ & (Nie et al., 2006) \\
Hong Kong & $0.028-6.3 \mathrm{ng} \cdot \mathrm{g}^{-1}$ & (Su et al., 2018) \\
Manoa Stream in Hawai'i (USA) & $51,900-89,420 \mathrm{pg} \mathrm{g}^{-1} \mathrm{lw}$ & (Yang et al., 2008) \\
\hline
\end{tabular}

Table 2: Relative Bioaccumulation of 2,4,4'-TCB in the tissues of Black Chin Tilapia (S. melanotheron) inhabiting Ologe Lagoon in the rainy and dry seasons

\begin{tabular}{|c|c|c|c|c|c|c|}
\hline & \multicolumn{6}{|c|}{ Sampling Stations } \\
\hline & \multicolumn{3}{|c|}{ Rainy Season } & \multicolumn{3}{|c|}{ Dry Season } \\
\hline & 1 & 2 & 3 & 1 & 2 & 3 \\
\hline BSAF & 1.28 & 1.09 & 1.51 & 5.48 & 0.48 & 14.15 \\
\hline BAF & - & - & $4.0075 \times 10^{-5}$ & - & - & - \\
\hline
\end{tabular}

BSAF-Biota to sediment accumulation factor (Fish : sediment); BAF-Bioaccumulation factor (Fish : surface water) 
Results from the bioaccumulation studies suggest that $2,4,4^{\prime}$-TCB was more bioavailable in the sediments in the lagoon than water. Studies have shown that sediments act as a sink for organic contaminants (Kumar and Singh, 2013; Pozo et al., 2014). These chemicals, due to their hydrophobicity and lipophilic characteristic adhere to sediments, thereby, making them bioavailable for organisms (Alkhatib and Weigand, 2002). The spatial difference in the biotasediment accumulation of $2,4,4^{\prime}-\mathrm{TCB}$ in the fish could be attributed to the varying distances of the zones from the source of industrial effluents and the behaviour of the fish as noted by Mourier et al., (2014).

Conclusion: Data from this study suggest that $S$. melanotheron could be safe for consumption with respect to PCBs contamination as the concentrations recorded in all the fish samples were consistently below WHO's safe limit. Conversely, the concentration of the compound in water from one of the zones in the rainy season was above USEPA's safe limit. This indicates that despite the negligible to low levels of the compound found in the environmental media of Ologe Lagoon, regular monitoring of the compound in the water body should not be neglected. This ensures that potentially toxic levels of the compound in Ologe Lagoon are forestalled.

\section{REFERENCES}

Adeogun, AO; Chukwuka, AV; Okoli, CP; Arukwe, A (2016). Concentration of polychlorinated biphenyl (PCB) congeners in the muscle of Clarias gariepinus and sediment from inland rivers of southwestern Nigeria and estimated potential human health consequences. J. Toxic. Environ. Health, Part A 79(21): 969-983.

Adeyemi, D; Ukpo, G; Anyakora, C; Uyimadu, J (2009). Polychlorinated biphenyl in fish samples from Lagos Lagoon, Nigeria. African Journal of Biotechnology 8(12): 2811-2815.

Alkhatib, E; Weigand, C (2002). Parameters affecting partitioning of 6 PCB congeners in natural sediments. Environmental Monitoring and Assessment 78(1): 1-17.

Amiard-Triquet, C, Amiard, JC; Mouneyrac, C (2015). Introduction; Aquatic Ecotoxicology: Advancing Tools for Dealing with Emerging Risks. Academic Press, Massachusetts.

Archibong, IE; Okonkwo, CJ; Wegwu, MO; Okonkwo, CJ (2017). Distribution and health risk assessment of selected endocrine disrupting chemicals in two fish species obtained from
Choba River in Rivers State, Nigeria. Bioengineering and Bioscience 5(4): 65-73.

Barakat, AO; Khairy, M; Aukaily, I (2013). Persistent organochlorine pesticide and PCB residues in surface sediments of Lake Qarun, a protected area of Egypt. Chemosphere 90(9): 2467-2476.

Beyer, A; Biziuk, M (2009). Environmental fate and global distribution of polychlorinated biphenyls. Reviews of Environmental Contamination and Toxicology 201: 137-158.

Breivik, K; Sweetman, A., Pacyna, JM; Jones, KC (2007). Towards a global historical emission inventory for selected PCB congeners-a mass balance approach: 3. An update. Science of the Total Environment 377(2-3): 296-307.

Combi, T; Taniguchi, S; Figueira, RCL; de Mahiques, MM; Martins, CC (2013). Spatial distribution and historical input of polychlorinated biphenyls (PCBs) and organochlorine pesticides (OCPs) in sediments from a subtropical estuary (Guaratuba Bay, SW Atlantic). Marine Pollution Bulletin 70 (1-2): 247-252.

de Souza, AS; Torres, JPM; Meire, RO; Neves, RC; Couri, MS; Serejo, CS (2008). Organochlorine pesticides (OCs) and polychlorinated biphenyls (PCBs) in sediments and crabs (Chasmagnathus granulata, Dana, 1851) from mangroves of Guanabara Bay, Rio de Janeiro State, Brazil. Chemosphere 73(1): 186-192.

Erickson, MD; Kaley, RG (2011). Applications of polychlorinated biphenyls. Environmental Science and Pollution Research 18(2), 135-151.

Ezemonye, LIN (2005a). Polychlorinated biphenyls (PCBs) levels and distribution in Ethiope and Benin Rivers of the Niger Delta, Nigeria: surface water and sediments. International Journal of Environmental Studies 62(5): 491-504.

Ezemonye, LIN (2005b). Levels Of Polychlorinated biphenyls residues in Warri River, Nigeria. Global Journal of Environmental Sciences 4(1): 65-71.

$\mathrm{Fu}, \mathrm{CT}$; $\mathrm{Wu}, \mathrm{SC}$ (2006). Seasonal variation of the distribution of PCBs in sediments and biota in a PCB-contaminated estuary. Chemosphere 62(11): 1786-1794.

Gao, S; Chen, J; Shen, Z., Liu, H; Chen, Y (2013). Seasonal and spatial distributions and possible 
sources of polychlorinated biphenyls in surface sediments of Yangtze Estuary, China. Chemosphere 91(6): 809-816.

Gioia, R., Akindele, A. J., Adebusoye, S. A., Asante, K. A., Tanabe, S., Buekens, A; Sasco, A. J (2013). Polychlorinated biphenyls (PCBs) in Africa: a review of environmental levels. Environ. Sci. Pollute. Res. 21(10): 6278-6289.

Gioia, R., Eckhardt, S., Breivik, K., Jaward, FM., Prieto, A., Nizzetto, L.; Jones, KC (2011). Evidence for major emissions of PCBs in the West African region. Environ. Sci. Technol. 45(4): 1349-1355.

Gonzalez, ST; Remick, D; Creton, R. and Colwill, RM (2016). Effects of embryonic exposure to polychlorinated biphenyls (PCBs) on anxietyrelated behaviors in larval zebrafish. Neurotoxicology, 53: 93-101.

Igbo, JK (2012). An investigation of polychlorinated biphenyl levels in two marine fish species Pseudotolithus senegalensis and Pseudotolithus carienensis. Journal of Basic and Applied Scientific Research 2 (4): 4315-4319.

Kampire, E; Rubidge, G; Adams, JB (2017). Characterization of polychlorinated biphenyls in surface sediments of the North End Lake, Port Elizabeth, South Africa. Water SA, 43(4): 646654.

Kim, AW; Vane, CH; Moss-Hayes, V; Engelhart, SE; Kemp, AC (2018). PAH, PCB, TPH and mercury in surface sediments of the Delaware River Estuary and Delmarva Peninsula, USA. Marine Pollution Bulletin 129(2): 835-845.

Kumar, AO; Singh, A (2013). Bioremediation of organic pollutant in sediment water interface: A review. International Journal of Engineering Research 8(7): 6-10.

Lerner, DT; Björnsson, BT; McCormick, SD (2007). Effects of aqueous exposure to polychlorinated biphenyls (Aroclor 1254) on physiology and behavior of smolt development of Atlantic salmon. Aquatic Toxicology 81 (3): 329-336.

Li, C; Huo, S; Yu, Z; Xi, B; Yeager, KM; He, Z; Wu, F (2017). National investigation of semi-volatile organic compounds (PAHs, OCPs, and PCBs) in lake sediments of China: occurrence, spatial variation and risk assessment. Sci. Total Environ. 579: 325-336.

Mackay, D; Fraser, A (2000). Bioaccumulation of persistent organic chemicals: Mechanism and models. Environ. Pollute. 110: 375-391.

Manirakiza, P; Covaci, A; Nizigiymana, L; Ntakimazi, G; Schepens, P. (2002). Persistent chlorinated pesticides and polychlorinated biphenyls in selected fish species from Lake Tanganyika, Burundi, Africa. Environ. Pollute. 117(3): 447455.

Moon, HB; Ok, G (2006). Dietary intake of PCDDs, PCDFs, and dioxinlike PCBs due to the consumption of various marine organisms from Korea. Chemosphere 62:1142-1152

Mourier, B; Desmet, M; Van Metre, PC; Mahler, BJ; Perrodin, Y; Roux, G; Babut, M (2014). Historical records, sources, and spatial trends of PCBs along the Rhône River (France). Sci.Total Environ. 476: 568-576.

Nakayama, K., Oshima, Y., Hiramatsu, K., Shimasaki, Y. and Honjo, T (2005). Effects of polychlorinated biphenyls on the schooling behavior of Japanese medaka (Oryzias latipes). Environmental Toxicology and Chemistry 24 (10): 2588-2593.

Necibi, M; Mzoughi, N (2017).The distribution of organic and inorganic pollutants in marine environment. Nova Science Publishers, New York.

Nie, XP; Lan, CY; An, TC; Wong, MH; Li, KB (2006). Distributions and congener patterns of PCBs in fish from major aquaculture areas in the Pearl River Delta, South China. Human and Ecological Risk Assessment: An International Journal 12(2): 363-373.

Obaje, SO (2013). Electronic waste scenario in Nigeria: Issues, problems and solutions. International Journal of Engineering Science Invention 2(11): 31-36.

Obanya, HE; Amaeze, NH; Togunde, O; Otitoloju, AA (2018). Air pollution monitoring around residential and transportation sector locations in Lagos Mainland. J. Health and Pollute. 8(19): 110 . 
Odabasi, M; Dumanoglu, Y; Kara, M; Altiok, H; Elbir, T; Bayram, A (2017). Spatial variation of PAHs and PCBs in coastal air, seawater, and sediments in a heavily industrialized region. Environmental Science and Pollution Research 24(15): 1374913759.

Okogwu, OI (2006). Physicochemical conditions and metal levels in Ologe Lagoon, Southwest, Nigeria. Afr. J. Environ. Pollut. Health 6(1): 28-31.

Okoh, MP (2015). Exposure to Organo-Chlorinated Compound, PolyChlorinated Biphenyl (PCB), environmental and public health Implications: A Nigeria Case study. International Journal of Chemical Studies. 2: 14-21.

Oluwatosin, M; Fatai, G; Akintade, O; Shehu, L; Oluwatoyin, J (2008). The dynamics of Desmidacean populations in Ologe lagoon, Lagos, Nigeria. Journal of Cell and Animal Biology 2(2): 21-30.

Pozo, K., Urrutia, R., Mariottini, M., Rudolph, A., Banguera, J., Pozo, K.; Focardi, S (2014). Levels of persistent organic pollutants (POPs) in sediments from Lenga estuary, central Chile. Marine Pollution Bulletin 79(1-2): 338-341

Said, TO; El Moselhy, KM; Rashad, AAM; Shreadah, MA (2008). Organochlorine contaminants in water, sediment and fish of Lake Burullus, Egyptian Mediterranean Sea. Bulletin of Environmental Contamination and Toxicology, 81(2): 136-146.

Ssebugere, P; Sillanpää, M; Kiremire, BT; Kasozi, GN; Wang, P; Sojinu, SO; Shang, H (2014). Polychlorinated biphenyls and hexachlorocyclohexanes in sediments and fish species from the Napoleon Gulf of Lake Victoria, Uganda. Science of the Total Environment 481: 5560 .

Su, Y; Bao, LJ; Zeng, EY (2018). Spatial Distribution of DDTs and PCBs in Wild Fish from Hong Kong Coastal Areas and Potential Human Health Risk Assessment. Huan jing ke xue= Huanjing kexue, 39(4): 1861-1871.

Tombesi, N; Pozo, K; Álvarez, M; Přibylová, P; Kukučka, P; Audy, O; Klánová, J (2017). Tracking polychlorinated biphenyls (PCBs) and polybrominated diphenyl ethers (PBDEs) in sediments and soils from the southwest of Buenos Aires Province, Argentina (South eastern part of the Grulac region). Sci. Total Environ. 575: 1470-1476.

Umulor, SO; Obanya, HE; Amaeze, NH; Okoroafor, CU (2018). Levels, Spatial and Seasonal Distribution of
Polybrominated Diphenyl Ethers (PBDEs) in Water, Sediments and Sarotherodon melanotheron from Ologe Lagoon. Asian J. Environment and Ecology, 8(1): 1-13.

United States Environmental Protection Agency (USEPA) (2003) Development of National Bioaccumulation Factors Methodology for Deriving Ambient Water Quality Criteria for the Protection of Human Health. http:/www.epa.gov/waterscience/criteria/humanhe alth/method/index.html. Accessed 27th April 2017.

United States EnvironmentalProtection Agency (USEPA) (2006a).Standard operating procedures: routine analysis of PCBs in water and soil/sediment samples by GC/ECD. Bethesda, MD: Scientific Engineering Response and Analytical Services. https://clu-in.org/download/ert/1801-r20.pdf. Accessed April 4 ${ }^{\text {th }} 2017$

USEPA (2009). National Primary Drinking Water Regulations. https://www.epa.gov/ground-waterand-drinking-water/TABLE-REGULATEDDRINKING-WATER-CONTAMINANTS. Accessed $2^{\text {nd }}$ January 2018.

USEPA (2006b). Ecological soil screening levels. Interim eco-SSLs and documentation, http://www.epa.gov/ecotox/ecossl/index.html. Accessed 27th April 2017.

Verhaert, V; Covaci, A; Bouillon, S; Abrantes, K; Musibono, D; Bervoets, L; Blust, R (2013). Baseline levels and trophic transfer of persistent organic pollutants in sediments and biota from the Congo River Basin (DR Congo). Environment International 59: 290-302.

World Health Organization and Food and Agriculture Organization (2011). Codex Alimentarius Commission: Strategic Plan 2008-2013, https://www.fao.org/docrep/010/a1384e/a1384e00. htm. Accessed $2^{\text {nd }}$ January 2018.

Yang, F; Wilcox, B; Jin, S.; Aguirre, AA; Rougée, L; Xu, $\mathrm{Y}$; Lu, Y (2008). Detection and quantitative analysis of polychlorinated biphenyls in tilapia from Hawaiian waters. Chemosphere 73(1): 133-137. 